\title{
ІСТОРИЧНІ ПЕРЕДУМОВИ ВИНИКНЕННЯ ТА СТАНОВЛЕННЯ КВАЗІДЕРЖАВНИХ УТВОРЕНЬ НА СХОДІ УКРАЇНИ
}

\author{
Олеся Звездова, \\ e-mail: zvezdova-ir@ukr.net \\ ORCID: https://orcid.org/oooo-ooo1-9664-5257 \\ Чорноморський національний університет імені Петра Могили, \\ Украӥна, 54оо3, м. Миколаїв, вул. 68 Десантників, 10
}

Стаття присвячена квазідержавним утворенням на Сході Украӥни. Визначені основні історичні передумови початку конфлікту: віддалене географічне розташування, імперська політика СРСР, наявність значної кількості російських мігрантів. Основними причинами конфлікту стали підтримка з боку РФ сепаратистсъких настроїв, участь в антиукрайнсъких акціях російсъких громадян, анексія Кримського півострову, прорахунки керівництва краӥни. На сучасному етапі першочерговою є проблема повного припинення війни на Сході Украӥни.

Ключові слова: Украйна, Російсъка Федерація, “ДНР/ЛНР», квазідержавні утворення, сепаратизм, Схід Украӥни

Постановка проблеми. Проблема існування «де-факто держав» на пострадянському просторі набула для України особливої актуальності у 2014 році, коли після Революції Гідності на Сході нашої держави активізувалися сепаратистські рухи і залунали ідеї щодо створення так званих «незалежних держав» «Донецька Народна Республіка» («ДНР») і «Луганська Народна Республіка» («ЛНР»). Військовий конфлікт призвів до втрати Україною контролю над деякими територіями Сходу і дав змогу проголосити ці регіони «де-факто державами» не лише сепаратистською владою, але й деякими державними російськими 3МI. Тому особливо гостро постає питання щодо визначення історичних передумов і справжнього статусу цих утворень.

Стан наукової розробки. Проблема вирішення конфлікту навколо сепаратистських регіонів на сході України є найбільш актуальною для вітчизняних дослідників, тому за останні роки з'явилася велика кількість публікацій із даної тематики. Незважаючи на відносну нетривалість самого конфлікту, корисним є дослідження історичних передумов, що склалися як результат політики Радянського Союзу. Етнолінгвістичні чинники, що зараз використовуються для виправдання існування незаконних утворень на території України, детально розглядаються у працях В. Скляра ${ }^{1}$ й О. Чиркова².

Об’єктом наукового дослідження Є. Рябініна ${ }^{3}$ є роль Російської Федерації у роздмухуванні конфлікту, підтримці так званих «ДНР/ЛНР». Науковець аналізує основні складові російської допомоги і наголошує на їі ключовій ролі у даному конфлікті.

\footnotetext{
${ }^{1}$ Скляр, В. (2016). Чисельність та етномовний склад населення не підпорядкованих Україні територій Донецької та Луганської областей. Наукові записки: IПіЕНД ім. І. Ф. Кураса НАН України. 5-6, 254-278.

2 Чирков, О.А. (2016). Етнічний чинник в агресії Російської Федерації проти України: етнокультурна історія південно-східних українських земель і сучасні маніпуляції Кремля. У П.П. ГайНижник (ред.). Агресія Росї проти Украӥни: історичні передумови та сучасні виклики. (с. 109-130). Київ: МП Леся.

3 Рябінін, Є. (2017). Основні складові екзогенної допомоги Росії «ДНР» та «ЛНР». UA Foreign Affairs. Retrieved from http://uaforeignaffairs.com/ua/ekspertna-dumka/view/article/osnovniskladovi-ekzogennoji-dopomogi-rosiji-dnr-ta/;
} 
Вагомий внесок у дослідження російсько-української війни зробив вітчизняний науковець П. Гай-Нижник. У своїй грунтовній праці «Росія проти України (19902016 рр.): від політики шантажу і примусу до війни на поглинання та спроби знищення»4 автор досліджує історичні і геополітичні передумови агресії Російської Федерації на Сході України і пропонує шляхи вирішення проблеми.

Основні перспективи розв’язання конфлікту, шляхи вирішення проблеми статусу окупованих територій, варіанти розвитку подій і прогнози на довгострокове майбутнє представлені в аналітичних доповідях Центру Разумкова5.

Результати та дискусії. Перш за все слід звернути увагу на історичні передумови назрівання конфлікту. Передумови для створення всіх «де-факто держав» на пострадянському просторі формувалися протягом XX ст., а каталізатором даного процесу став розпад Радянського Союзу. На відміну від цих прикладів жодних значних сепаратистських тенденцій на початку 90-х років XX ст. на Сході України зафіксовано не було.

Але не слід вважати, що сучасний конфлікт не мав історичних передумов. Український дослідник О. Дергачов зазначає: «Період існування союзного договору і фактично унітарної держави - СРСР мав своїм наслідком заглиблення України у євразійський політичний та економічний простір, виникнення стану її всебічної залежності» ${ }^{6}$ Схід України в результаті близькості до кордонів із Росією став найбільш схильним до поглиблення такої залежності. Отже, корені сучасного протистояння слід знову шукати в етнонаціональній політиці спочатку Російської імперії, а потім СРСР, що призвело до слабкої консолідованості громадян цих регіонів. На думку українського дослідника О. Чиркова, об’єктивними причинами цього є:

- віддалене, периферійне географічне розташування відносно столиці 3 потужними регіональними центрами;

- історично зумовлена (в умовах Російської імперії та СРСР) етнокультурна «зросійщеність» великої частки громадян;

- наявність серед місцевих мешканців значної кількості російських мігрантів та їхніх нащадків у першому і другому поколіннях7.

На підтвердження останньої тези слід навести статистичні дані національного складу Донецької і Луганської областей. Донецька область (до 1961 року - Сталінська область) у сучасних межах була утворена 3 червня 1938 року, коли з ії складу було виокремлено сучасну Луганську область (що мала назву до 1958 року і з 1970 по 1990 рік Ворошиловградська область). Тому першим переписом населення, який дає нам чітку картину національного складу громадян двох областей, будемо вважати загальносоюзний перепис населення 1939 року $^{8}$. За 50 років існування областей у складі СРСР кількість росіян значно збільшилася за рахунок зменшення кількості українців на цих територіях (на 12,4\% і на 11,9\% у Донецькій і Луганській областях відповідно)9.

Враховуючи масове переселення до 1939 року на ці території росіян після Голодомору 1932-1933 pp., можна зробити висновок, що національний склад сучасних Донецької і Луганської областей зазнав суттєвих змін за роки існування Радянського Союзу.

\footnotetext{
4 Гай-Нижник, П.П. (2017). Росія проти Украӥни (1990-2016 рр.): від політики шантажу $i$ примусу до війни на поглинання та спроби знищення. Київ: МП Леся, 231.

5 Російсько-український конфлікт: стан, наслідки, перспективи розвитку подій. Аналітична доповідь Центру Разумкова. (2014). Національна безпека і оборона. 5-6.

6 Дергачов, О. (1996). Украӥнська державність у XX столітті: Iсторико-політологічний аналіз. Київ: Політична думка. Retrieved from http://litopys.org.ua/ukrxx/r15.htm

7 Чирков, О.А. (2016). Вказ. пр.

8 Всесоюзная перепись населения 1939 года. Национальный состав населения районов, городов и крупных сел союзных республик СССР. (2017). Демоскоn Weekly: Институт демографии Национального исследовательского университета Высшая школа экономики. Retrieved from http://demoscope.ru/weekly/ssp/ussr_nac_39_ra.php?reg=46

9 Державний комітет статистики України. (2002). Про кількість та склад населення Украӥни за підсумками Всеукраӥнсъкого перепису населення 2001 року. Retrieved from http://2001.ukrcensus.gov.ua/results/general/nationality/
} 
Після набуття Україною незалежності кількість українців у цих регіонах почала повільно збільшуватися, про що свідчать дані першого (і до цього дня останнього) Всеукраїнського перепису населення 2001 р. На жаль, ці дані є досить застарілими, але офіційного перепису населення за ці 16 років не відбувалося. Наступний черговий перепис переносився декілька разів і був запланований врешті-решт на 2016 р. Але анексія Криму і події на Сході України змусили керівництво держави заради об'єктивності результатів знову перенести дату перепису на листопад-грудень 2020 р.

Всеукраїнський перепис населення 2001 р. продемонстрував, що кількість населення, яка позиціонувала себе як українці, у відсотковому співвідношенні до загальної кількості населення виросла на 6\% та у порівнянні з переписом 1989 р. у Донецькій і Луганській областях склала 2744,1 тис. осіб і 2540,2 тис. осіб відповідно. Кількість росіян у цих областях (38-39\%) була найвищої у відсотковому значенні серед усіх інших регіонів України, враховуючи АРК (де вона складала всього 24,3\%)10.

Отже, незважаючи на деякі тенденції до зростання відношення українського населення до російського за роки незалежності у даних регіонах, загальна картина національно складу областей значно відрізняється від середніх показників по Україні. До того ж Загальноукраїнський перепис 2001 р. наочно продемонстрував, що розподіл населення Донецької і Луганської областей України за рідною мовою кардинально відрізняється від загальноукраїнського розподілу. Якщо по Україні у відсотках до загальної чисельності населення українську мову назвали рідною 67,53\%, то у ДО і ЛО цей показник склав 24,1\% і 30,01\% відповідно. I навпаки, російську мову назвали рідною 74,92\% і 68,84\% (по Україні - всього 29,39\%). Отже, незважаючи на певне збільшення українського населення в регіоні, частка україномовного навіть зменшилася у порівнянні з радянськими часами (у 1989 році в Донецькій області вона складала 30,54\%, а в Луганській - 34,66\%) ${ }^{11}$.

Український дослідник В. Скляр пропонує таке пояснення: «Такі істотні відмінності в чисельності та в рівні частки україномовного населення та українців серед усього населення Донбасу були спричинені інерційним впливом етномовних процесів доби бездержавності. Українці опинилися в становищі підпорядкованої етнічної більшості, а домінантний статус посідала російська етнічна меншина. Тому значна частина українців виявилася зросійщеною за мовою, а рівень мовної українізації етнічних меншин, а особливо росіян, залишався досить незначним ${ }^{12}$. Також це може буде пояснено недостатньою увагою української влади мовному питанню у перші роки незалежності.

Не $\epsilon$ дивним, що лінгвістичний і національний фактори робили населення даних регіонів України більш вразливим перед російською пропагандою і схильним до сепаратистських настроїв. Перші прояви цього стали помітними після подій «помаранчевої революції» 2004 р. 26 листопада 2004 р. депутатами Луганської обласної ради було прийнято рішення «Про зміцнення організаційної структури місцевої влади в Луганській області», де серед інших положень було встановлено: «Внести на розгляд з"їзду органів місцевого самоврядування та виконавчої влади Південно-Східних територій України пропозицію про організацію робочої групи зі створення і формування податкової, платіжної, банківської, фінансової системи Південно-Східних територій»13.

Наступний крок відбувся через два дні на Першому Всеукраїнському з"їді депутатів усіх рівнів у Сєверодонецьку. Ініціативу вже взяла Донецька обласна рада, голова якої Б. Колесников запропонував провести референдум і створити Автономну Пів-

10 Державний комітет статистики України. (2002). Про кількість та склад населення Украӥни за підсумками Всеукраӥнського перепису населення 2001 року. Retrieved from http://2001.ukrcensus.gov.ua/results/general/nationality/

11 Державний комітет статистики України. (2002). Розподіл населення регіонів Украӥни за рідною мовою (за даними Всеукраӥнсъкого перепису населення 2001 року). Retrieved from http://2001.ukrcensus.gov.ua/i/u/cens2001.pdf

${ }_{12}$ Скляр, В. (2016). Вказ. пр., 254-278.

13 Луганский областной совет. (2004). Об укреплении организационной структуры местной власти в Луганской области. Retrieved from http://oblrada.lg.ua/node/2159 
денно-Східну Українську Республіку (АПСУАР) зі столицею в Харкові14. Українські дослідники зазначали, що прототипом АПСУАР може бути Донецько-Криворізька Радянська Республіка - штучне державне автономне утворення у складі більшовицької Росії, яке проіснувало з 9 лютого по 19 березня 1918 року.

Практичного розвитку проект, що був засуджений центральною владою, не отримав. А проти деяких ініціаторів (наприклад, Є. Кушнарьова й О. Єфремова) порушили карні справи за посягання на територіальну цілісність України, але ці справи також не були доведені до логічного кінця. Цей факт став одним із показників безкарності сепаратизму в Україні, що спричинило повернення до цього питання вже у 2005 р., коли О. Цуркан заснував обласну громадську організацію «Донецька Республіка». У 2006 р. організація почала збір підписів, отримавши на це дозвіл від мерії, про проведення референдуму щодо «незалежності Донбасу ... як це зробило Придністров'я» та створення «Донецької федеративної республіки», в яку повинні були ввійти Донецька, Дніпропетровська, Луганська, Херсонська й Запорізька області 15. Дана громадська організація була заборонена у 2007 р., проте її активісти продовжували сепаратистську діяльність і подавали апеляції до 2013 р.

Події листопада 2013 - лютого 2014 рр., що отримали назву Революція Гідності, стали показником європейських прагнень українського суспільства і водночас засвідчили остаточний вихід України з пострадянського проекту. Але, нажаль, саме ці події стали каталізатором для поновлення сепаратистських рухів на Сході держави.

Перший етап сучасного конфлікту на Сході України розпочався у березні 2014 р., коли в Донецькій і Луганській областях виникли масові заворушення під відверто сепаратистськими і проросійськими гаслами. Серед основних внутрішніх і зовнішніх факторів, що їх спричинили, дослідники з Українського центру економічних і політичних досліджень імені Олександра Разумкова виділили наступні:

- інспірування та підтримка з боку РФ сепаратистських настроїв на Донбасі, безпосередня участь в антиукраїнських акціях російських громадян (осіб у військовій формі, але без розпізнавальних знаків ${ }^{16}$. Наприклад, український дослідник П. ГайНижник стверджує, що екстремістські акції у цих регіонах ініціювалися та управлялися мережею координаторів Головного розвідувального управління Російської Федерації17;

- масована інформаційна кампанія російських 3МI, що значно посилила традиційні проросійські настрої серед значної частини жителів Донбасу й неприйняття ними «нової київської влади». Наприклад, слід згадати видання «Російської газети в Україні», яка, офіційно не порушуючи українське законодавство, була відверто проросійською і постійно пропагувала ідеї культурної та ідеологічної єдності з РФ18. До речі, ця газета продовжувала надходити в Україну навіть після початку конфлікту на Сході, а ii російський примірник відрізняється досить лояльним ставленням до сепаратистських угрупувань у нашій державі.

- анексія Кримського півострову у березні 2014 р. й висвітлення цієї події російськими 3MI як «свята єдності», що надало потужний політико-психологічний імпульс сепаратистським рухам на Сході України;

- деякі прорахунки постреволюційного керівництва країни. До таких прикладів можна віднести спробу Верховної Ради скасувати Закон України «Про засади

14 Нас штовхають у ПіСУАР. (2012). Украйнський тиждень. Retrieved from http://tyzhden.ua/Politics/66863

15 Проект «Донецкой Республики» на Украине существовал давно - еще при Ющенко. (2015). Московский комсомолец. Retrieved from http://www.mk.ru/politics/article/2014/o4/o7/1010242proekt-donetskoy-respubliki-na-ukraine-suschestvoval-davno-esche-pri-yuschenko.html

16 Російсько-український конфлікт: стан, наслідки, перспективи розвитку подій. Аналітична доповідь Центру Разумкова. (2014). Національна безпека і оборона, 5-6, 4.

17 Гай-Нижник, П.П. (2017). Вказ. пр., 231.

18 «Российская газета» всё ещё «в Украине». (2015). MediaSapiens. Retrieved from http://osvita.mediasapiens.ua/trends/mediacriticism/rossiyskaya_gazeta_vse_esche_v_ukraine/ 
державної мовної політики» 22 лютого 2014 р. Деякі політики і політологи вважали цей крок передчасним, враховуючи нестабільну ситуацію в державі у перший день після остаточного повалення режиму В.Януковича. Наприклад, один із лідерів опозиції під час Євромайдану В. Кличко у своєму інтерв’ю стверджував: «Насправді це рішення було неправильним. До даного питання потрібно було підходити не сьогодні, а через місяць, через два. Ми цей закон тепер повинні переглянути»19. Український письменник А. Кокотюха вказує на те, що у тій ситуації провокації могли б грунтуватися і на будь-яких інших чинниках ${ }^{20}$. На користь цієї позиції свідчить і той факт, що в.о. Президента О. Турчинов ветував закон про скасування мовного закону, але він тим не менш був використаний проросійською пропагандою як свідчення утисків російської мови з боку нової центральної влади та став одним із приводів для активізації сепаратистських рухів на Сході України.

Другий етап характеризувався більш активними й агресивними діями проросійських сепаратистів: спочатку озброєні підрозділи почали захоплювати адміністративні будівлі; у м. Слов'янску, м. Артемівську й інших містах почалися активні бойові дії. Кульмінацією даного етапу стало проголошення 7 квітня 2014 р. так званої «Донецької народної республіки»²1. А через 20 днів про свою так звану незалежність заявила і «Луганська народна республіка» 22.

У відповідь на ці події О. Турчинов як в.о. Президента України 14 квітня фактично започаткував антитерористичну операцію (АТО) на Сході, ввівши своїм указом в дію рішення РНБО України «Про невідкладні заходи з подолання терористичної загрози і збереження територіальної цілісності країни»23.

Тим часом сепаратисти зробили спробу легалізувати свої незаконні рішення і провели у травні 2014 р. на цих територіях нелегітимний референдум про суверенітет. За даними так званих «ДНР» і «ЛНР» абсолютна більшість населення (89,07\% і 96\% відповідно) проголосували за відокремлення від України та проголошення незалежності, але світова спільнота не визнала ці референдуми ${ }^{24}$. Також неодноразово лунали заклики до Російської Федерації ввести свої війська на територію сепаратистських регіонів заради «нормалізації ситуації» і захисту «російськомовного населення».

Таким чином, конфлікт перейшов у фазу відкритого військового протистояння. Ця фаза ускладнювалася прямою (військове втручання) і непрямою (економічна, фінансова, інформаційна, гуманітарна, дипломатична допомоги) підтримкою сепаратистських регіонів з боку Російської Федерації25.

Участь російських військових формувань, яка до цього часу повністю заперечується РФ, але підтверджується даними СБУ, Міноборони, РНБО, Прикордонної служби України, вітчизняних і міжнародних експертів, НАТО, російських правозахисників ${ }^{26}$,

19 Кличко: «Мы пересмотрим закон о языках» (интервью Я. Соколовской). (2014). Известия. Retrieved from https://iz.ru/news/566556

20 Кокотюха, А. Чи винен «мовний закон» у вторгненні Росії в Україну. (2017). Главред. Retrieved from http://glavred.info/avtorskie_kolonki/chi-vinen-movniy-zakon-u-vtorgnenni-rosiyi-vukrayinu-273593.html

${ }^{21}$ Сепаратисти проголосили створення «Донецької республіки» та «увійшли» до Росії. (2014). Украйнсъка правда. Retrieved from http://www.pravda.com.ua/news/2014/04/7/7021595/

22 У Луганську проголосили «Луганську народну республіку». (2014). Радіо Свобода. Retrieved from http://www.radiosvoboda.org/media/video/25364473.html

23 Верховна Рада України. (2014). Рішення Ради національної безпеки і оборони Украӥни від 28 серпня 2014 року «Про невідкладні заходи щздо захисту Украӥни та зміцнення иї обороноздатності». Retrieved from http://zakon2.rada.gov.ua/laws/show/noo11525-14

24 Луганські сепаратисти оголосили остаточні результати «референдуму». (2014). Украӥнсъка правда. Retrieved from http://www.pravda.com.ua/news/2014/05/12/7025091/

25 Рябінін, Є. (2017). Основні складові екзогенної допомоги Росії «ДНР» та «ЛНР». UA Foreign Affairs. Retrieved from http://uaforeignaffairs.com/ua/ekspertna-dumka/view/article/osnovniskladovi-ekzogennoji-dopomogi-rosiji-dnr-ta/

${ }^{26}$ Російсько-український конфлікт: стан, наслідки, перспективи розвитку подій. Аналітична доповідь Центру Разумкова. (2014). Національна безпека і оборона, 5-6, 8. 
значно ускладнила ситуацію і дала змогу зберегти сепаратистським угрупуванням владу на певних територіях. Це підтверджують і самі сепаратисти, наприклад, російський військовий І. Гіркін у своєму інтерв’ю стверджував: «Якби наш загін не перейшов кордон, у підсумку все б закінчилось, як у Харкові, як в Одесі... А практично маховик війни, що досі триває, запустив наш загін... Від самого початку ми почали воювати всерйоз»27. А 27 січня 2015 р. Верховна Рада України визнала Російську Федерацію агресором²8.

Старший науковий співробітник Атлантичної ради А. Каратницький запропонував наступний поділ учасників військових формувань, що беруть участь у конфлікті на боці так званих «ДНР/ЛНР»:

- місцеві злочинні угрупування;

- безробітні чоловіки з найбідніших верств суспільства;

- політичні екстремісти з Росії, включаючи козаків;

- російські найманці, які воювали в Придністров”і, Чечні, Південній Осетії, інших регіональних конфліктах на пострадянському просторі 29.

Вони пройшли підготовку, оснащені сучасною зброєю, підтримуються російськими регулярними і спеціальними військами. У цих сепаратистських анклавах переважають добре озброєні кримінальні банди, лідери яких відіграють ключову роль у місцевій політиці, як офіційно, позиціонуючи себе урядовими лідерами, так і неофіційно, як вожді банд із власними цілями.

Активна фаза збройного протистояння тривала до початку 2015 р., у цей період, за даними Управління Верховного комісара Організації Об'єднаних Націй з прав людини, було вбито щонайменше 7962 людини (включаючи військових українських збройних сил, цивільних осіб та членів збройних угруповань), і щонайменше 17811 осіб отримали пораненнязо. У ході складного переговорного процесу за участі ОБСЕ, що буде розглянутий у наступному розділі, вдалося досягти перемир'я відповідно до Мінського протоколу від 5 вересня 2014 р. й Мінської угоди від 12 лютого 2015 р. Але і сьогодні конфлікт залишається в активній фазі й не може вважатися замороженим, тому що постійно тривають позиційні бої на лінії зіткнення. У 2018 р. на офіційному сайті Управління ООН з координації гуманітарних питань було зазначено, що за 4 роки російсько-українського конфлікту на Сході України більше 2540 цивільних осіб загинули і 9 тис. отримали поранення ${ }^{31}$.

Щодо кількості населення, то точних даних отримати неможливо, зважаючи на окупацію території і незаконність переписів, які проводять там так звані «управління статистики ЛНР/ДНР». За даними електронного перепису населення, які Кабінет міністрів України оприлюднив 23 січня 2020 р., станом на 1 грудня 2019 р. в Донецькій і Луганській областях населення скоротилось на 59\% і 56\% відповідно32. Україн-

${ }_{27}^{27}$ Кто ты, «Стрелок»? (интервью с И. Стрелковым). (2014). Газета «Завтра». Retrieved from http://zavtra.ru/blogs/kto-tyi-strelok

28 Постанова Верховної Ради України Про Звернення Верховної Ради України до Організації Об’єднаних Націй, Європейського Парламенту, Парламентської Асамблеї Ради Європи, Парламентської Асамблеї НАТО, Парламентської Асамблеї ОБСЄ, Парламентської Асамблеї ГУАМ, національних парламентів держав світу про визнання Російської Федерації державоюагресором. (2015). Відомості Верховної Ради (ВВР), 10, 68.

29 Karatnycky, A. (2015, June 9). Putin's Warlords Slip Out of Control. The New York Times. Retrieved from https://www.nytimes.com/2015/o6/10/opinion/putins-warlords-slip-out-of-control.html?_r=1 $3^{\circ}$ Office of the United Nations High Commissioner for Human Rights. (2015). Report on the human rights situation in Ukraine 16 May to 15 August. Retrieved from http://www.ohchr.org/Documents/Countries/UA/11thOHCHRreportUkraine.pdf

${ }^{31}$ United Nations Office for the Coordination of Humanitarian Affairs. (2018, February 28). Ukraine: Four years of conflict leave $4.4 \mathrm{M}$ people in dire need of humanitarian assistance. Retrieved from http://www.unocha.org/story/ukraine-four-years-conflict-leave-44m-people-dire-need-

humanitarian-assistance

32 Урядовий портал. (2020). Оприлюднено результати оцінки чисельності наявного населення Украӥни. Retrieved from https://www.kmu.gov.ua/news/oprilyudneno-rezultati-ocinkichiselnosti-nayavnogo-naselennya-ukrayini 
ський дослідник В. Скляр припускає: «В окупованому Донбасі, з депресивним характером його економіки, можна передбачити подальше скорочення кількості населення, насамперед внаслідок депопуляції та міграції, на регіон чекає невтішна доля невизнаної Придністровської Молдавської республіки, де за 20 років загальна кількість населення скоротилася майже вдвічі»33.

Висновки. Отже, серед основних історичних передумов конфлікту на Сході України можна виділити: віддалене, периферійне географічне розташування відносно столиці, імперську політику СРСР, наявність серед місцевих мешканців значної кількості російських мігрантів. Основними причинами конфлікту стали підтримка 3 боку РФ сепаратистських настроїв на Донбасі, безпосередня участь в антиукраїнських акціях російських громадян, масована інформаційна кампанія російських $3 \mathrm{MI}$, анексія Кримського півострову, деякі прорахунки українського керівництва.

Перший етап сучасного конфлікту на Сході України розпочався у березні 2014 р., коли в Донецькій і Луганській областях виникли масові заворушення під відверто сепаратистськими і проросійськими гаслами. Другий етап характеризувався більш активними й агресивними діями проросійських сепаратистів. Після проведення нелегітимних референдумів на території Донецької та Луганської областей почалася фаза відкритого військового протистояння, яка ускладнювалася прямою підтримкою сепаратистських регіонів з боку Російської Федерації та тривала до початку 2015 р.

Генеза конфлікту навколо так званих «ДНР/ЛНР» може стати базою для його «замороження», що в свою чергу несе певні загрози для національної безпеки України:

1. Ускладнення майбутнього процесу реінтеграції держави за рахунок змін у масовій свідомості населення регіонів шляхом інформаційної війни і проросійської пропаганди протилежної сторони.

2. Активізація державотворчих процесів в окупованому регіоні, що надасть можливість сепаратистській владі посилити контроль над територією і сприятиме їі легітимізації.

3. Продовження побудови відносин із Російською Федерацію, пряма допомога та вплив якої дозволить регулювати економічну і соціальну сфери життя на окупованих територіях і зробить владу бойовиків більш привабливою в очах населення.

Першочерговою є проблема повного припинення війни на Сході України, що не дозволяє зосередити увагу на відновленні контролю над окупованими територіями, реінтеграції цих регіонів до українського політичного простору. На даному етапі їх статус $\epsilon$ визначеним українським законодавством як тимчасово окупованих територій.

\section{REFERENCES}

Chyrkov, O.A. (2016). Etnichnyi chynnyk v ahresii rosiiskoi federatsii proty Ukrainy: etnokulturna istoriia pivdenno-skhidnykh ukrainskykh zemel i suchasni manipuliatsii Kremlia [Ethnic factor in the aggression of the Russian Federation against Ukraine: the ethno-cultural history of the southeastern Ukrainian lands and the modern manipulation of the Kremlin]. In P.P. Hai-Nyzhnyk (Ed.), Ahresiia Rosii proty Ukrainy: istorychni peredumovy ta suchasni vyklyky (pp. 109-130). Kyiv: MP Lesia. [in Ukrainian].

Derhachov, O. (1996). Ukrainska derzhavnist u XX stolitti: Istoryko-politolohichnyi analiz [Ukrainian Statehood in the XX Century: Historical and Political Analysis]. Kyiv: Politychna dumka. Retrieved from http://litopys.org.ua/ukrxx/r15.htm [in Ukrainian].

Derzhavnyi komitet statystyky Ukrainy. (2002). Pro kilkist ta sklad naselennia Ukrainy za pidsumkamy Vseukrainskoho perepysu naselennia 2001 roku [About the number and composition of the population of Ukraine according to the results of the 2001 All-Ukrainian Population Census]. Retrieved from http://2001.ukrcensus.gov.ua/results/general/nationality/ [in Ukrainian].

Derzhavnyi komitet statystyky Ukrainy. (2002). Rozpodil naselennia rehioniv Ukrainy za ridnoiu movoiu (za danymy Vseukrainskoho perepysu naselennia 2001 roku) [Distribution of the population of regions of Ukraine in their native language (according to the 2001 All-Ukrainian Population Census)]. Retrieved from http://2001.ukrcensus.gov.ua/i/u/cens2001.pdf [in Ukrainian].

33 Скляр, В. (2016). Вказ. пр., 276. 
Hai-Nyzhnyk, P.P. (2017). Rosiia proty Ukrainy (199o-2016 rr.): vid polityky shantazhu i prymusu do viiny na pohlynannia ta sproby znyshchennia [Russia vs. Ukraine (1990-2016): From Blackmail and Coercion Policy to War to Absorption and Destruction Attempts]. Kyiv: MP Lesia. [in Ukrainian]

Karatnycky, A. (2015, June 9). Putin's Warlords Slip Out of Control. The New York Times. Retrieved from https://www.nytimes.com/2015/o6/10/opinion/putins-warlords-slip-out-ofcontrol.html?_r=1 [in English].

Klichko: My peresmotrim zakon o iazykakh (interviu Sokolovskoi) [Klichko: We will revise the law on languages (interview with Y.Sokolovskaya)]. (2014). Izvestiia. Retrieved from https://iz.ru/news/566556 [in Russian].

Kokotiukha, A. (2017). Chy vynen «movnyi zakon» u vtorhnenni Rosii v Ukrainu [Is the «language law» guilty of Russia's invasion of Ukraine]. Hlavred. Retrieved from http://glavred.info/avtorskie_kolonki/chi-vinen-movniy-zakon-u-vtorgnenni-rosiyi-v-ukrayinu273593.html [in Ukrainian].

Kto ty, Strelok: interviu s I. Strelkovym [Who are you, Shooter? (interview with I. Strelkov)]. (2014). Gazeta Zavtra. Retrieved from http://zavtra.ru/blogs/kto-tyi-strelok [in Russian].

Luganskyi oblastnoi sovet. (2004). Ob ukreplenii organizatsionnoi struktury mestnoi vlasti $v$ Luganskoi oblasti [On strengthening the organizational structure of local authorities in the Luhansk region]. Retrieved from http://oblrada.lg.ua/node/2159 [in Russian].

Luhanski separatysty oholosyly ostatochni rezultaty «referendumu» [Lugansk separatists announce the final results of the "referendum"]. (2014). Ukrainska pravda. Retrieved from http://www.pravda.com.ua/news/2014/05/12/7025091/ [in Ukrainian].

Nas shtovkhaiut u PiSUAR [We are being pushed into the PiSUAR]. (2012). Ukrainskyi tyzhden. Retrieved from http://tyzhden.ua/Politics/66863 [in Ukrainian].

Office of the United Nations High Commissioner for Human Rights. (2015). Report on the human rights situation in Ukraine 16 May to 15 August. Retrieved from http://www.ohchr.org/Documents/Countries/UA/11thOHCHRreportUkraine.pdf [in English].

Postanova Verkhovnoi Rady Ukrainy Pro Zvernennia Verkhovnoi Rady Ukrainy do Orhanizatsii Ob’iednanykh Natsii, Yevropeiskoho Parlamentu, Parlamentskoi Asamblei Rady Yevropy, Parlamentskoi Asamblei NATO, Parlamentskoi Asamblei OBSIe, Parlamentskoi Asamblei HUAM, natsionalnykh parlamentiv derzhav svitu pro vyznannia Rosiiskoi Federatsii derzhavoiuahresorom [The Verkhovna Rada of Ukraine Resolution on the Verkhovna Rada of Ukraine's Appeal to the United Nations, the European Parliament, the Parliamentary Assembly of the Council of Europe, the NATO Parliamentary Assembly, the OSCE Parliamentary Assembly, the GUAM Parliamentary Assembly, and the national parliaments on the recognition of the Russian Federation as an aggressor]. (2015). Vidomosti Verkhovnoi Rady (VVR), 10, 68. [in Ukrainian].

Proekt Donetskoi Respubliki na Ukraine sushchestvoval davno eshche pri Iushchenko [The project of the «Donetsk Republic» in Ukraine has existed for a long time - even under Yushchenko]. (2014). Moskovskii komsomolets. Retrieved from http://www.mk.ru/politics/article/2014/04/07/ 1010242-proekt-donetskoy-respubliki-na-ukraine-suschestvoval-davno-esche-priyuschenko.html [in Russian].

Riabinin, Ye. (2017). Osnovni skladovi ekzohennoi dopomohy Rosii «DNR» ta «LNR» [The main components of Russian exogenous aid to «DNR» and «LNR»]. UA Foreign Affairs. Retrieved from http://uaforeignaffairs.com/ua/ekspertna-dumka/view/article/osnovni-skladoviekzogennoji-dopomogi-rosiji-dnr-ta/ [in Ukrainian].

Rossiiskaia gazeta vse eshche v Ukraine [Rossiyskaya Gazeta is still in Ukraine]. (2015). MediaSapiens. Retrieved from http://osvita.mediasapiens.ua/trends/mediacriticism/rossiyskaya_gazeta_vse_esche_v_ukraine/ [in Russian].

Rosiisko-ukrainskyi konflikt: stan, naslidky, perspektyvy rozvytku podii. Analitychna dopovid Tsentru Razumkova [The Russian-Ukrainian conflict: state, consequences, prospects]. (2014). Natsionalna bezpeka i oborona. 5-6. [in Ukrainian].

Separatysty proholosyly stvorennia «Donetskoi respubliky» ta «uviishly» do Rosii [The separatists proclaimed the creation of a «Donetsk Republic» and «entered» into Russia]. (2014). Ukrainska pravda. Retrieved from http://www.pravda.com.ua/news/2014/04/7/7021595/ [in Ukrainian].

Skliar, V. (2016). Chyselnist ta etnomovnyi sklad naselennia ne pidporiadkovanykh Ukraini terytorii Donetskoi ta Luhanskoi oblastei [The size and ethnic composition of the population of the not subordinated to Ukraine territories of Donetsk and Luhansk regions]. Naukovi zapysky: IPiEND im. I.F. Kurasa NAN Ukrainy, 5-6, 254-278. [in Ukrainian]. 
U Luhansku proholosyly «Luhansku narodnu respubliku» [The Lugansk People's Republic was proclaimed in Lugansk]. (2014). Radio Svoboda. Retrieved from http://www.radiosvoboda.org/media/video/25364473.html [in Ukrainian].

United Nations Office for the Coordination of Humanitarian Affairs. (2018, February 28). Ukraine: Four years of conflict leave 4.4M people in dire need of humanitarian assistance. Retrieved from http://www.unocha.org/story/ukraine-four-years-conflict-leave-44m-people-dire-needhumanitarian-assistance [in English].

Uriadovyi portal. (2020). Opryliudneno rezultaty otsinky chyselnosti naiavnoho naselennia Ukrainy [The results of the estimation of the population of the Ukrainian population are published]. Retrieved from https://www.kmu.gov.ua/news/oprilyudneno-rezultati-ocinkichiselnosti-nayavnogo-naselennya-ukrayini [in Ukrainian].

Verkhovna Rada Ukrainy. (2014). Rishennia Rady natsionalnoi bezpeky i oborony Ukrainy vid 28 serpnia 2014 roku «Pro nevidkladni zakhody shchodo zakhystu Ukrainy ta zmitsnennia yii oboronozdatnosti» [Decision of the National Security and Defense Council of 28 August 2014 «On urgent measures to protect Ukraine and strengthen its defense capability»]. Retrieved from http://zakon2.rada.gov.ua/laws/show/noo11525-14 [in Ukrainian].

Vsesoiuznaia perepis naseleniia 1939 goda. Natsionalnyi sostav naseleniia raionov gorodov i krupnykh sel soiuznykh respublik SSSR [Union Population Census of 1939. The national composition of the population of regions, cities and large villages of the Union republics of the USSR]. Demoskop Weekly Institut demografii Natsionalnogo issledovatelskogo universiteta Vysshaia shkola ekonomiki. Retrieved from http://demoscope.ru/weekly/ssp/ ussr_nac_39_ra.php?reg=46 [in Russian]

Olesia Zvezdova,

Petro Mohyla Black Sea National University, Mykolaiv, Ukraine ORCID: https://orcid.org/oooo-ooo1-9664-5257

\section{Historical background of the quasi-state entities emergence and formation in East of Ukraine}

This article deals with quasi-state entities in eastern Ukraine. The main historical prerequisites for the beginning of the conflict are identified: remote, peripheral geographical location relative to the capital, imperial policy of the USSR, the presence of a significant number of Russian migrants among the local inhabitants. The main causes of the conflict were the support of the separatism in the Donbass by the Russian Federation, direct participation in anti-Ukrainian actions of Russian citizens, a massive information campaign of the Russian media, annexation of Crimea, some mistakes of the Ukrainian power.

The first stage of the modern conflict in eastern Ukraine began in March 2014. Mass riots broke out in Donetsk and Luhansk regions under openly separatist and pro-Russian slogans. The second stage was characterized by more active and aggressive actions of the pro-Russian separatists. The phase of open military confrontation began after the holding of illegitimate referendums in the territory of Donetsk and Lugansk regions. This stage was complicated by the direct Russian support of the separatist regions. The active phase of the armed confrontation continued until early 2015. Their status is defined by the Ukrainian legislation as temporarily occupied territories. At the present stage, the priority is the complete cessation of war in the east of Ukraine, which does not allow to focus on regaining control over the occupied territories, reintegration of these regions into the Ukrainian political space.

It is forecasted that the genesis of the conflict over the so-called «DPR/LPR» may become the basis for its «freezing». It may complicate the future process of state reintegration. The changes in the mass consciousness of the population of the regions through information war and pro-Russian propaganda of the opposite side and activation of state-building processes in the occupied region are threats to the national security of Ukraine.

Key words: Ukraine, Russian Federation, «DPR / LPR», quasi-state entities, separatism, East of Ukraine 